\title{
Water Circulations on La Soufrière Volcano Inferred by Self-Potential Surveys (Guadeloupe, Lesser Antilles). Renew of Volcanic Activity?
}

\author{
J. ZLOTNICKI ${ }^{1}$, M. FeUILLARD ${ }^{2}$, and G. HAMMOUYA ${ }^{2}$ \\ ${ }^{1}$ Laboratoire de Géophysique d'Orléans, 3 av de la Recherche Scientifique, 45071 Orléans cedex 2, France \\ et Département des Observatoires Volcanologiques (IPGP) \\ ${ }^{2}$ Observatoire Volcanologique de la Soufrière de Guadeloupe, Institut de Physique du Globe de Paris, \\ 97120 Le Parnasse, ST CLAUDE, France
}

(Received April 26, 1993; Revised June 14, 1994; Accepted June 15, 1994)

\begin{abstract}
Soufrière volcano is an andesite explosive volcano located in Guadeloupe in the lesser Antilles arc. Since the last magmatic eruption dated $1440 \pm 40 \mathrm{AD}$ several violent phreatic eruptions have occurred. The two last 1956 and 1976-1977 phreatic/phreato magmatic eruptions were preceded by several decades of quietness. During these quiet periods, hydrothermalization and argillization are expanding due to high tropical rainfalls ( 10 to $12 \mathrm{~m}$ per year). Sealing of fractures yields more and more difficult the release of thermal stresses developed by the magmatic body supposed to be at $6 \mathrm{~km}$ depth. Overpressures are increasing in confined superficial water tables.

Renew of seismic activity started in May 1992. About 1400 earthquakes were recorded between May and December 1992. The onset of activity was preceded, one year before, by a slight increase of vapor emission inside South crater located on Soufrière dome at the upper end of August 30, 1976 fault, by the reactivation of the small Tarade hot spring dried up since the 1976-1977 eruption, and by the appearance of a new, low flow rate, hot spring called Pas du Roy (about $30^{\circ} \mathrm{C}$ ).

A Self Potential (S.P.) survey has been performed in July 1992 on Soufrière massif. The S.P. anomalies evidence structural heterogeneities and ground waters flowing within the massif. A large, smooth, positive S.P. anomaly, composed of two localized and pronounced anomalous zones, is spreading on the south-west-south-east sector of the dome basis. The larger anomalous zone is located on Morne Mitan in the axis of the regional Ty and August, 30, 1976 faults. This zone is extending along the contact zone between Soufrière dome and Carmichaël cone. The 1992 survey is compared with 1987 survey. Soufrière dome is now submitted to a ring of positive S.P. anomalies which are lying along the inner part of Amic crater. The positive anomalous zone located on Morne Mitan has developed since 1987. The second anomalous zone, located on the south-west part of the dome, was not observed in 1987. The amplitude reaches $200 \mathrm{mV}$. The S.P. mapping points out that warm ground water beneath the south part of the volcano summit, along clayey beds, could generate the collapse of the south-west-south-east sector of Soufrière dome.
\end{abstract}

\section{Introduction}

Soufrière of Guadeloupe is a calc-alkaline $1467 \mathrm{~m}$ high volcano $\left(16^{\circ} 02^{\prime} \mathrm{N}, 61^{\circ} 04^{\prime} \mathrm{W}\right)$. The magmatic eruption giving rise to the present Soufrière dome burst in $1440 \pm 40 \mathrm{AD}$ (Vincent et al., 1979). The dome takes place in Grande Découverte composite volcano inside the horseshoe shape Amic crater caused by a 3100 year B.P. flank collapse (Boudon et al., 1987) (Figs. 1A and 1B).

Only phreatic eruptions have occurred after the bulding of Soufrière dome: The most important eruptions took place in 1797-1798, 1836-1838, 1956 and 1976-1977 (Jolivet, 1958; Robson and Tomblin, 1966; IPG report, 1976). Strong thermal activity is expressed by the existence of old hydrothermalized areas, ancient hydrothermal clays within debris-avalanche deposits, large fumarolic areas, and many faults or fractures in which-10-12 meters-annual rainfalls are swallowed up. During quietness periods ground thermal activity is weakening and shifting to the periphery of Soufrière dome. 
After some years the activity is only focusing along major tectonic accidents like the regional Ty fault and Morne Mitan (Figs. 1A and 1B) (Jolivet, 1958). The slow argillization is taking place in superficial geological beds (Pascaline et al., 1982; Pham et al., 1990; Zlotnicki et al., 1992). Superficial phreatic water tables are becoming isolated from each others. Concurrently, seismicity is decreasing and remaining at a very low level (some ten of quakes per year with magnitudes less than 1). Renew of seismicity started in May 1992. Piton Tarade outcrop $\left(26.5^{\circ} \mathrm{C}\right)$, dried up since the 1976-1977 seismovolcanic crisis, was reactivated. In January 1992 a small outcrop, called Pas du Roy, appeared $1.3 \mathrm{~km}$ south-west of Soufrière dome. After a peak of seismicity in June 1992 the number of quakes decreased till December 1992.

The Self Potential mapping is an image of the electric potential reduced to a relative reference point. Measurements of static Self-Potential (S.P.) anomalies were firstly used in geothermal and minerals prospectings (Sato and Mooney, 1960; Zodhy et al., 1973; Corwin and Hoover, 1979). This method was developed on volcanoes to evidence thermal anomalies and fluids circulations in the subsurface (Zablocki, 1976). On volcanoes S.P. anomalies are mainly due to electrokinetic effects (Mitzutani et al., 1976; Fitterman, 1978; Massenet and Pham, 1985; Ballestracci and Nishida, 1987). Due to pressure gradients fluids carry on ions (generally positive) in the interconnected pore networks. If fluids - upwelling of ground water or wet steam-go up towards the volcano surface a positive S.P. anomaly appears at the ground level. Positive S.P. anomalies are associated with low resistive and high ground temperature zones. Negative anomalies are produced by meteoric water percolating through a massif. S.P. values decrease from $1 \mathrm{mV}$ to $10 \mathrm{mV}$ as elevation increases $1 \mathrm{~m}$. The ratio $\Delta(V) / \Delta(H)$, where $V$ and $H$ are respectively the potential and the altitude, is called electrokinetic coupling coefficient $C$. High S.P. anomalies up to 2 volts have been sometimes measured on volcanoes (Aubert and Kieffer, 1984; Massenet and Pham, 1985; Jackson and Kauahikaua, 1987; Nishida and Tomiya, 1987; Lénat, 1987; Ishido et al., 1989; Zlotnicki et al., 1994). Most often these positive anomalies are due to hydrothermal circulations.

Soufrière volcano has taken place inside Amic crater and has developed a concentric contact zone. The dome is parcelled by superficial radial faults. The large rainfalls percolate through the massif and wash the gas escaping from the faults and the fumarolic areas. The tropical climate emphasizes the argillization and the mineralization of scoria, pumices, and lava. Induced thermal exchanges generate

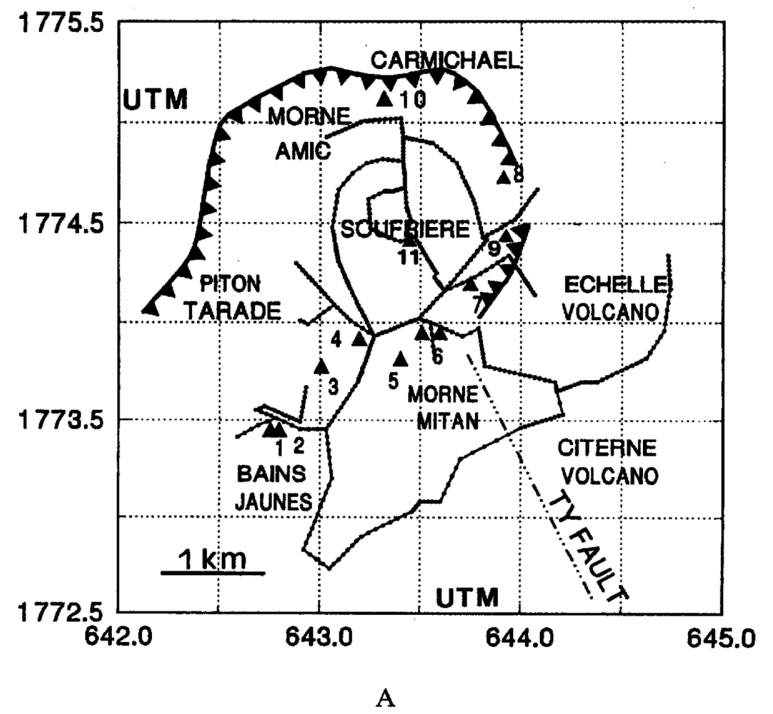

Fig. 1. A: S.P. surveys. 1: Bains Jaunes outcrop, 2: Pas du Roy outcrop, 3: Tarade outcrop, 4: Savane à Mûlets borehole, 5: Galion outcrop, 6: Morne Mitan fumarolic area, 7: Col de l'Echelle borehole, 8: Carbet-Echelle outcrop, 9: died ChaudièresSouffleur fumarolic area, 10: died Colardeau fumarolic area, 11: South crater. B: Schematic sketch of Soufrière massif. 
convective hydrothermal cells along structural accidents. Mineralized ground waters and temperature contrasts should be the source of Self Potential anomalies.

A previous S.P. map of Soufrière of Guadeloupe, made in June 1987, pointed out that Soufrière was mainly the seat of meteoric waters percolating through the massif emphasizing the argillization of the edifice (Pham et al., 1990). In July 1992, we have performed a larger S.P. cartography to evidence possible increases of anomalous thermal areas and ground water channellings associated with the renewal of volcanic activity of Soufrière volcano.

\section{General Behaviour of Soufrière Volcano}

\subsection{The phreatic 1956 eruption}

In the years preceding the eruption, the weak fumarolic activity was surrounded to the dome periphery (Jolivet, 1958). In 1956 weak fumarolic activity appeared in the vicinity of Lacroix fumaroles, and then, on the dome along the future east-south-east 1956 fracture. Temperatures at hot springs remained

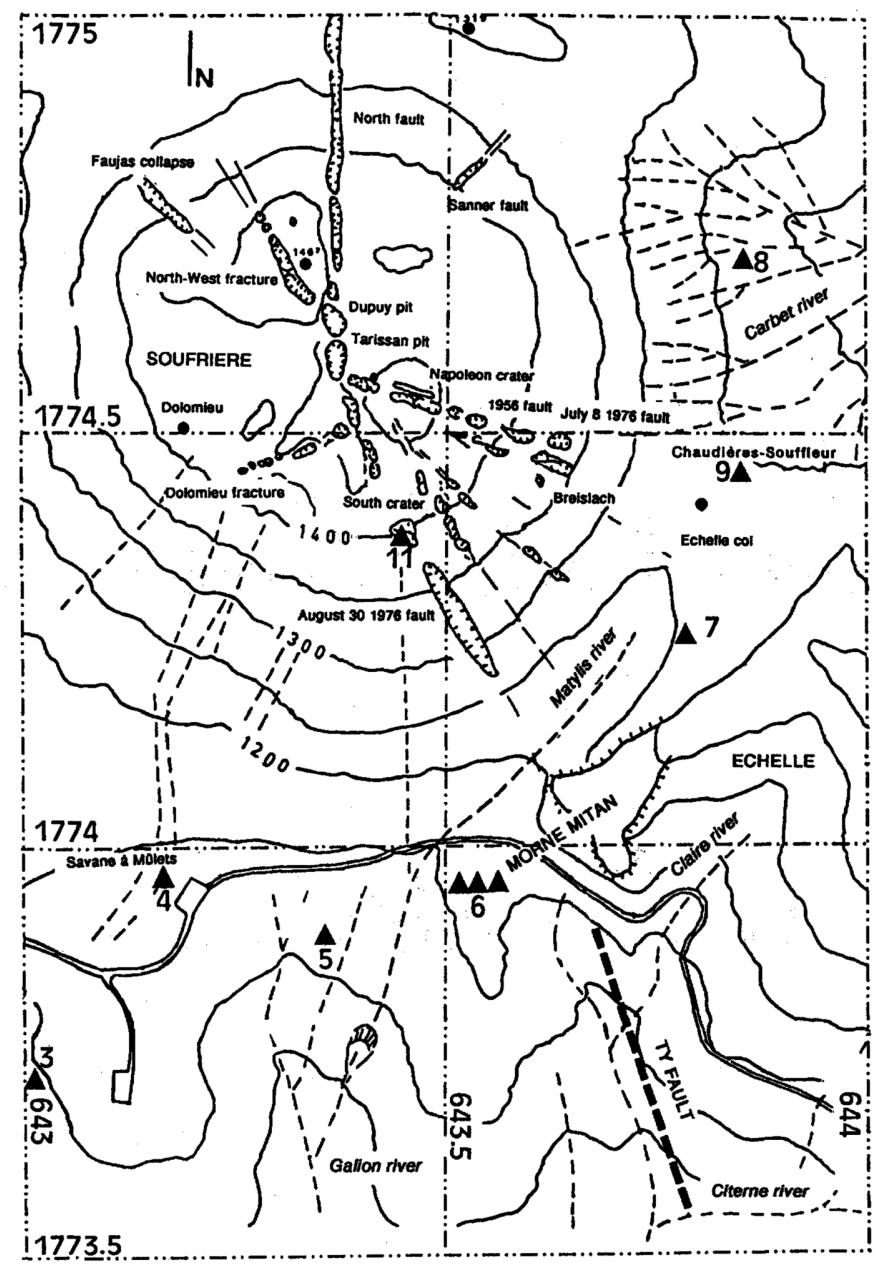

B

Fig. 1. (continued). 
constant. The eruption started on October 20,1956, after a few months of seismic events, opening fractures on the east-south-east dome flank. The eruptive activity decreased two months later and furmarolic activity receded from the dome itself (Dorel et al., 1972).

\subsection{The 1976-1977 phreatic/phreatomagmatic eruption}

Seismic activity sharply started in November 1975 with 209 earthquakes (Fig. 2) (Dorel and Feuillard, 1980). The first landslide occurred in June 1976 in Galion river, and the first phreatic explosion (July 8, 1976) reopened the east-south-east 1956 fracture. From September, 1976, the volcanic activity progressively receded (Feuillard et al., 1983; Zlotnicki, 1986). Till 1992, only five short time seismic swarms beneath the dome or its immediate vicinity were recorded (Table 1). These seismic crises could be interpreted either by some release of thermal energy in superficial confined water tables (see Goguel, 1977), or by modifications of the hydrothermal fluids pattern around the phreatic waters (Bigot and Hammouya, 1987).

Between 1984 and 1992 seismicity continuously decreased till 46 recorded events in 1991 (Fig. 2). Geochemical parameters measured at hot springs indicated a clogging up of the massif (Bigot and Hammouya, 1987). Fumarolic activity vanished from the dome and migrated towards the periphery, along the largest active fault (August 30, 1976), and on Morne Mitan (Figs. 1A and 1B). Only South crater remained active on Soufrière dome. Argillization became preponderant and constituted impermeable clayey beds (Pascaline et al., 1982; Zlotnicki et al., 1992). Soufrière dome was mainly the seat of meteoric waters going through the massif till argillous beds without any global thermal exchanges with deep hot sources (Pham et al., 1990).

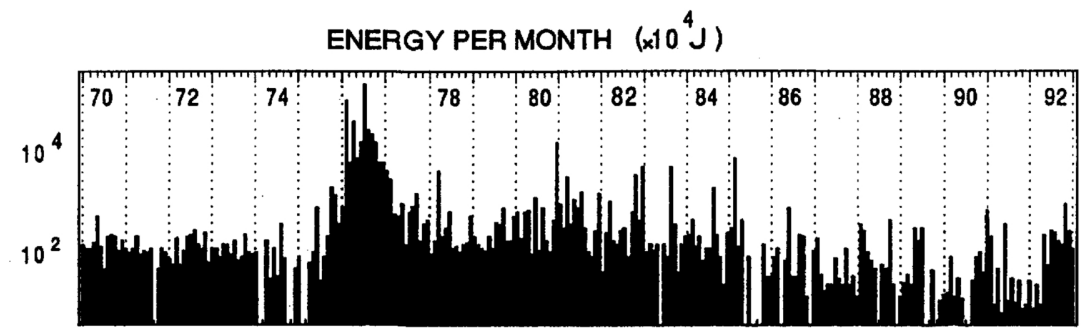

NUMBER OF QUAKES PER MONTH

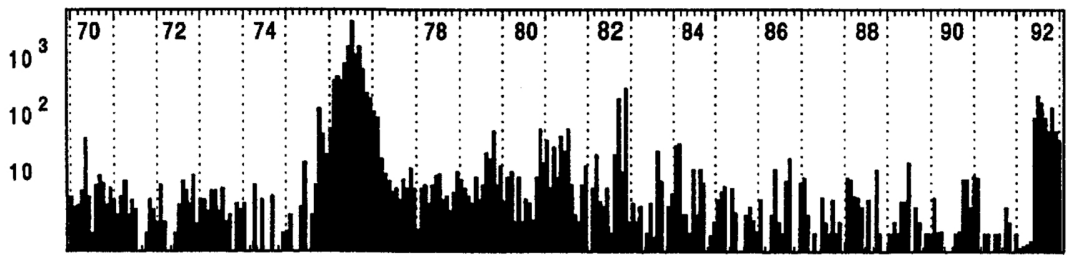

Fig. 2. Seismic activity between 1970 and 1992.

Table 1. Number and energy of the seismic crises between 1976 and 1992.

\begin{tabular}{lccccc}
\hline & Jan. 7-8 & Nov. 22-24 & Jan. 8-9 & Oct. 16-17 & Oct. 15 \\
& 1981 & 1982 & 1983 & 1983 & 1984 \\
\hline Number & 58 & 209 & 346 & 27 & 13 \\
Energy $\left(\times 10^{6}\right.$ Joules $)$ & 297 & 40 & 64 & 78 & 17 \\
\hline
\end{tabular}




\subsection{Renew of volcanic activity: May 1992}

Vapor activity in South crater slightly strengthened in 1991 and extended towards the dome center (Napoléon crater, Tarissan pit). Tarade spring $\left(26.5^{\circ} \mathrm{C}\right)$, dried up after the 1976 seismovolcanic crisis, began to flow again. A new hot spring (called Pas du Roy, about $30^{\circ} \mathrm{C}$, less than $11 / \mathrm{sec}$ ) appeared at the end of 1991 near Bains jaunes hot springs (Fig. 1A).

During the first 4 months of 1992, the seismic activity was very weak with only 14 earthquakes. The onset of activity started on May 21 with 30 events. The monthly maximum number was reached in June with 370 quakes while the monthly energy peak was observed in October. In December 1992 about 1400, low magnitude $(<2)$, earthquakes were recorded and the cumulative energy was less than $4 \times 10^{7}$ Joules. Earthquakes were localized beneath Soufrière dome and its nearby periphery at a depth less than $3 \mathrm{~km}$ below the sea level.

\section{Self Potential Mapping}

Most often geothermal fields and volcanoes are submitted to circulations of ground waters. Sources of electric potentials are produced by the separation and the displacement of ions in electrolytic media (Zablocki, 1976). The streaming potential is the main mechanism (electrokinetic effect) by an order of magnitude compared with thermoelectric and electrochemical potentials (Corwin and Hoover, 1979). The streaming potential is generated by the flow of ground waters in porous media when a pore pressure gradient is applied. A part of positive charges are adsorbed by the rock matrix along the path of the water flow. The other part of positive charges generates a positive current flow in the direction of the fluid flow. The potential is positive at the ground surface. When meteoric water percolates through the ground by gravitational forces, the streaming potential becomes negative at the ground surface. In this case, a simple linear relationship, called topographic effect, between the potential and the topography is observed. The associated coefficient is constant by segments and several authors suggest a correlation between this coefficient and the vadose-zone thickness (Corwin and Hoover, 1979; Jackson and Kauahikaua, 1987).

We have made the S.P. mapping of Soufrière volcano in July 1992. About $15 \mathrm{~km}$ of profiles have been measured with a mean sampling rate of $25 \mathrm{~m}(50 \mathrm{~m}$ at the worst, Fig. $1 \mathrm{~A})$. Impolarisable $\mathrm{Pb}-\mathrm{PbCl}_{2} \mathrm{Probes}$ with a thermal drift of $1 \mu \mathrm{V} /{ }^{\circ} \mathrm{C}$ have been used. The probes were regulary checked several times along each profile. The discrepancy has never exceeded a few $\mathrm{mV}$ at each point. The input impedance of the voltmeter was $100 \mathrm{M} \Omega$. The soil has enough moist to insure good contacts during the experiments. The surveys are computed to the same relative reference $\mathrm{R}$ located outside the active part of Soufrière volcano, at the south-east dome foot of Echelle cone. S.P. values are averaged on three points $(75 \mathrm{~m}$ or $150 \mathrm{~m}$ depending on the spatial scale of S.P. anomalies on each survey). Let us discuss the main S.P. surveys.

\subsection{Pas du Roy-Morne Mitan-Citerne volcano profile}

The survey starts from the south-west side of Soufrière dome near Bains Jaunes and Pas du Roy hot springs, goes along the south flank of the volcano and rejoins Citerne volcano (Fig. 1A). This profile goes through major tectonic axes like Ty fault, Soufrière dome-Echelle cone contact zone, fumarolic areas, and hot springs. The most developed fumarolic area covers Morne Mitan which has always remained more or less active $\left(96^{\circ} \mathrm{C}\right)$. Ground water circulations are evidenced at Galion hot springs $\left(43^{\circ} \mathrm{C}\right.$ in 1992, Fig. 1A). Temperature measured at $100 \mathrm{~m}$ depth in Savane à Mûlets borehole is about $29^{\circ} \mathrm{C}$ in 1992 (see Feuillard, 1976).

Steep S.P. variations, up to $200 \mathrm{mV}$, are observed along the profile (Figs. 3A and 8). Both extremities of the survey are outside the hydrothermal area of the volcano: they present a negative linear correlation between S.P. values and the altitude corresponding to ground water flowing by gravity effect (topographic effect, Figs. 3B and 3C). Except the sharp negative S.P. anomaly lying at the north-west side of Citerne volcano one can observe clear relative positive S.P. anomalies. From the western end of the profile, a smooth anomaly is evidenced between Bains Jaunes hot springs and Savane à Mûlets (Bains Jaunes anomaly on Figs. 3A and 3B). In less than $100 \mathrm{~m}$, the anomaly is sharply enhanced of about $60 \mathrm{mV}$ at the south- 

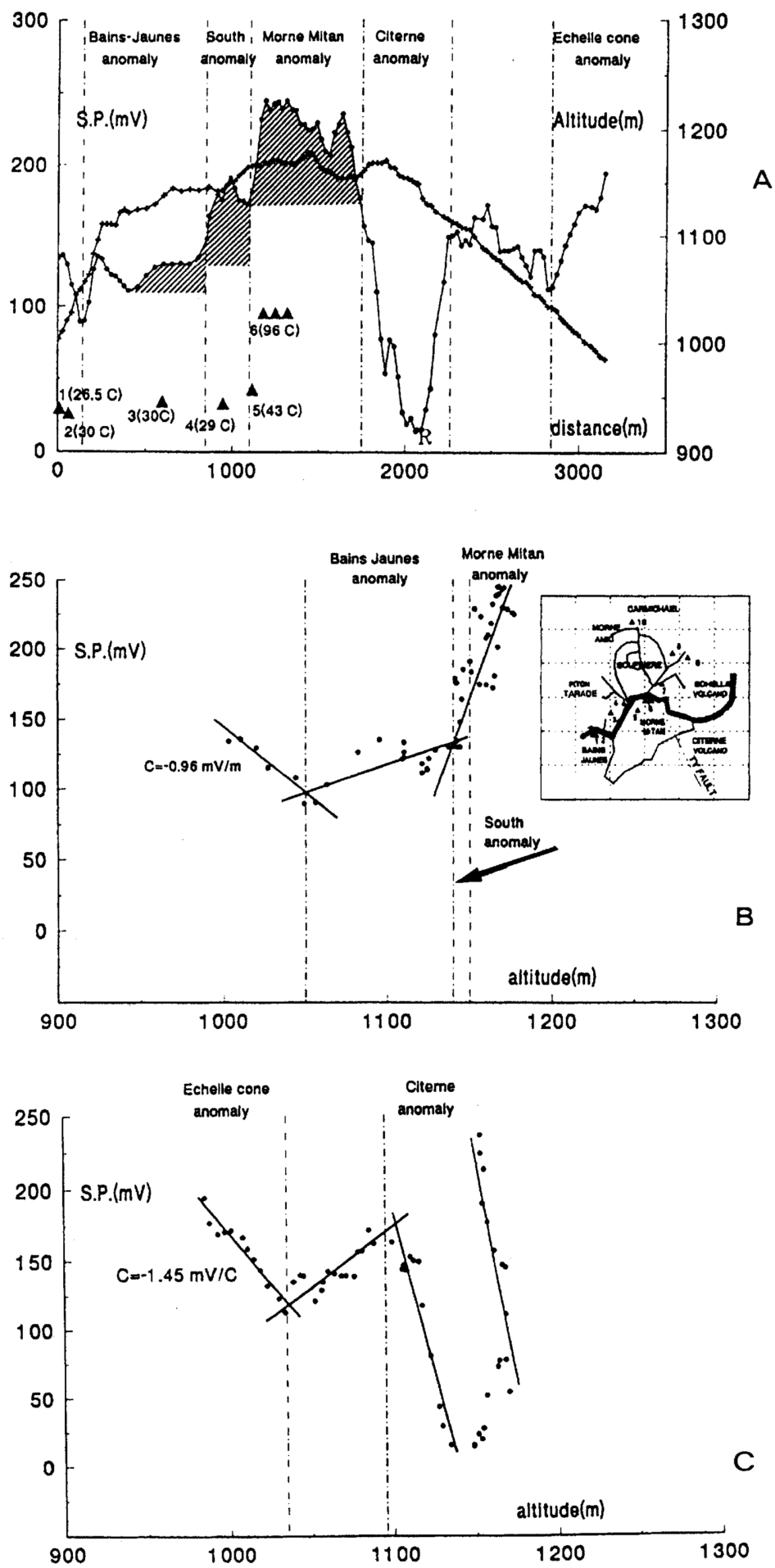

Fig. 3. A: S.P. anomalies and associated topography of Pas du Roy-Morne Mitan-Citerne volcano profile versus distance. See Fig. 1 for the signification of triangles. Dashed areas correspond to positive anomalous zones. B: S.P. values versus altitude till Morne Mitan anomaly. C: S.P. values versus altitude of the east part of the survey. 
west basis of Soufrière dome. A second sharp increase of $75 \mathrm{mV}$ is observed $150 \mathrm{~m}$ before Morne Mitan crest (Morne Mitan anomaly on Figs. 3A and 3B). These positive S.P. anomalies disappear on the south flank of Echelle cone (Citerne anomaly).

The positive S.P. anomalies point out the areas of the convections cells flowing upwards (Jackson and Kauahikaua, 1987). It is well in accordance with the location of the main tectonic units: Ty and August 30, 1976 faults, Morne Mitan, Soufrière dome-Echelle cone contact zone, Galion outcrop. Meteoric water flows into the tectonic accidents, are reheated as it goes deeper, and is trapped by inclined impermeable argillous beds giving rise to warm ground water circulations and outcrops. It is noteworthy that the west flank of the S.P. anomalies are steep. They could be associated with buried accidents: the step variation between South and Morne Mitan anomalies is in the alignment of the North fault and Galion outcrop (Fig. 1B). These accidents could limit the spreading to the west of ground water flows centered on Morne Mitan at the junction Soufrière dome-Echelle cone. This assumption is supported by high temperatures on Morne Mitan $\left(96^{\circ} \mathrm{C}\right)$ and at Galion outcrop $\left(43^{\circ} \mathrm{C}\right.$ ), and weaker temperatures on the west hand side (Savane à Mûlets borehole, Tarade, Bains Jaunes, Pas du Roy, about $26-30^{\circ} \mathrm{C}$ ).

From Bains Jaunes hot springs to Soufrière south flank the S.P. survey reveals a $1000 \mathrm{~m}$ wide smooth anomaly which could be associated with the numerous, low temperature, hot springs. The contact zone between Piton Tarade and Soufrière dome is not so steep as Soufrière dome-Echelle cone one (part of Amic crater wall). This observation could explain why S.P. anomalies are of larger extend.

\subsection{Chemin des Dames profile}

Chemin des Dames survey turns around Soufrière dome in an anticlockwise with the same starting and ending point located near Savane à Mûlets borehole (Figs. 1A, 4B and 4C).

A step positive anomaly $(75 \mathrm{mV})$ begins $150 \mathrm{~m}$ before Morne Mitan in the North fault axis (Fig. 4A). This anomaly remains till the north extremity of Echelle col. On this section, recent faults like those of August 30, 1976, Breislach, 1956 and July 8, 1976 do not produce any individual noticeable anomaly. After Echelle col a meaningful correlation exists between negative S.P. anomalies and major faults or fractures (Sanner fault, North fault, Faujas collapse, Dolomieu fracture, Figs. 4A, 4B, 4C and 8). The largest negative anomalies, up to $-100 \mathrm{mV}$, are associated with the quiet north part of the dome: North fault and Faujas collapse. On the north border of Dolomieu fracture, a sharp increase of about $120 \mathrm{mV}$ is observed although there is no trace at the ground surface (Fig. 4A).

The opposite behaviour of the S.P. anomalies with the existing faults, on the south-west-south-east and on the east'north'south-west dome sectors, is clearly depending on thermal transfers between heated upwards fluids and downwards meteoric water. Negative S.P. anomalies show meteoric water going downwards without thermal exchanges with upwards reheated fluids. This observation agrees with the slow displacement with time, towards the south, of the fumarolic areas located along the circle arc: north of Morne Amic (Colardeau fumaroles), Carbet-Echelle hot spring, Chaudières-Souffleur, Echelle col borehole, Morne Mitan (Jolivet, 1958). This trace straightly corresponds to the inner caldera walls of Amic crater in which Soufrière dome has taken place (Boudon et al., 1987). Positive S.P. anomalies are mainly due to superficial phreatic water tables, confined along the contact zone, and reheated by means of deep fractures (Pascaline et al., 1982; Bigot and Hammouya, 1987). These thermal exchanges can be independent of the fumarolic activity developed on Soufrière dome itself. The weak positive S.P. anomalies associated with the recent faults, like August 30, 1976, Breislach, 1956 and July 8, 1976 faults, suggest that the southeast dome part is essentially clayey and the seat of weak homogenous thermal exchanges. For instance Carbet-Echelle hot spring and the water table, beneath Echelle borehole, have kept the same decreasing temperature behaviour in the last years $\left(1979: 96^{\circ} \mathrm{C}, 1992: 39^{\circ} \mathrm{C}\right)$.

\subsection{Morne Mitan-Echelle cone profile}

The spatial extent of the positive anomalies developed along the contact zone between Soufrière dome and Echelle cone is determined by the profile (Figs. 5A and 8): Morne Mitan to Echelle summit. The positive S.P. anomaly slightly extends beyond Echelle borehole, but sharply disappears on 

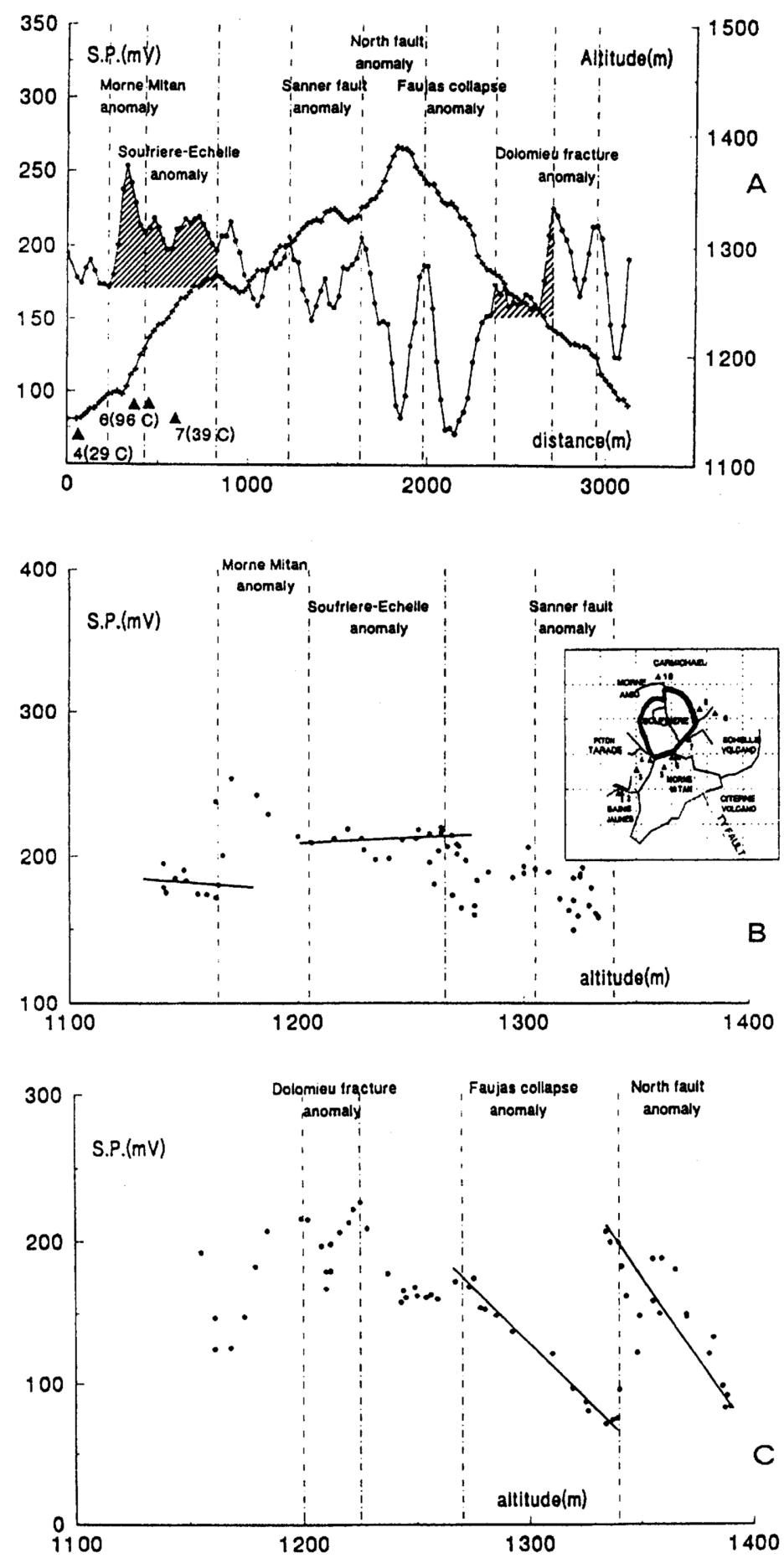

Fig. 4. A: S.P. anomalies and associated topography of Chemin des Dames profile versus distance. See Fig. 1 for the signification of triangles. Dashed areas correspond to positive anomalous zones. B: S.P. values versus altitude till Sanner fault anomaly. C: S.P. values versus altitude beyond Sanner fault anomaly. 
Echelle cone slope (Fig. 5A). A well known topographic effect is observed ( $-2.12 \mathrm{mV} / \mathrm{m}$, Fig. 5B). The minimum S.P. value is reached on Echelle summit (relative drop $-130 \mathrm{mV}$ ). The survey outlines thermal exchanges strictly located along the inner part of Amic crater; outside of the crater meteoric water percolates through the massif along the inclined watershed beds of Echelle cone. Therefore, the phreatic water table cut by Echelle borehole is the expression of a superficial water circulation regime (the water table is of weak volume and is quite dependant of the rainy seasons).

\subsection{Morne Mitan-North fault profile}

The profile starts on Morne Mitan, goes along the north side of August 30,1976 fault till South crater on Soufrière summit, and reaches the North fault by the west hand side (Figs. 1A and 1B).

Well defined S.P. anomalies are observed (Figs. 6A and 8). Positive S.P. anomalies are lying beyond Morne Mitan and Soufrière-Echelle contact zone (see also Fig. 5A), S.P. values are decreasing with the elevation (from $1230 \mathrm{~m}$ to $1280 \mathrm{~m}:-4 \mathrm{mV} / \mathrm{m}$ ). From $1280 \mathrm{~m}$ to South crater $(1440 \mathrm{~m}$ ) two small positive anomalies (less than $50 \mathrm{mV}$ ) are superimposed to a constant trend. These two anomalies are to be
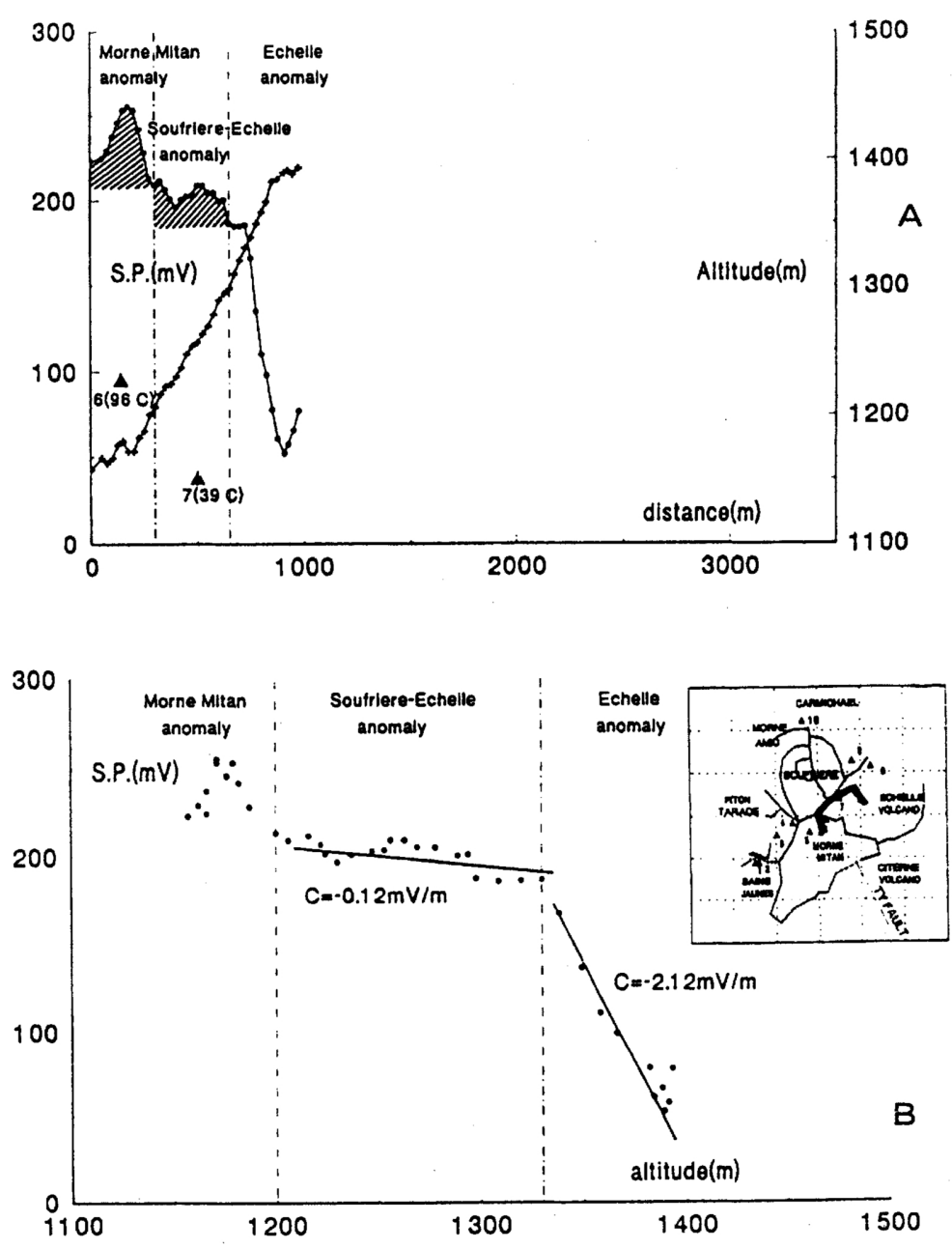

Fig. 5. A: S.P. anomalies and associated topography of Morne Mitan-Echelle cone survey versus distance. See Fig. 1 for the signification of triangles. Dashed areas correspond to positive anomalous zones. B: S.P. values versus altitude. 
associated with the upper part of August 30, 1976 fault and South crater (Fig. 6B). On the summit the positive S.P. anomaly is spreading till Dolomieu, about $200 \mathrm{~m}$ on the west hand side, while the S.P. anomaly is vanishing on the north of Napoléon crater (about $150 \mathrm{~m}$ ) (Fig. 1B). To the north the profile points out a sharp negative S.P. anomaly, centered on Faujas collapse and North-West fracture, the amplitude of which exceeds $170 \mathrm{mV}$.

The 1976-1977 seismovolcanic crisis has been mainly dominated by the formation and the activity of August 30, 1976 fault. In 1992 the activity along the fault is weak and only localized on short segments (Fig. 6B). The amplitude of Morne Mitan S.P. anomaly is about $260 \mathrm{mV}$ while the amplitude at the upper active end of the fault is only $140 \mathrm{mV}$. Morne Mitan-North fault survey expresses thermal exchanges on Soufrière summit. In the lower part of August 30, 1976 fault S.P. values show a negative variation with altitude (Fig. 6B): there is no up raise of warm fluids. The positive S.P. anomaly starts at the lower trace of August 30, 1976 fault and goes on till the summit. It corresponds to the active part of the fault (Julien
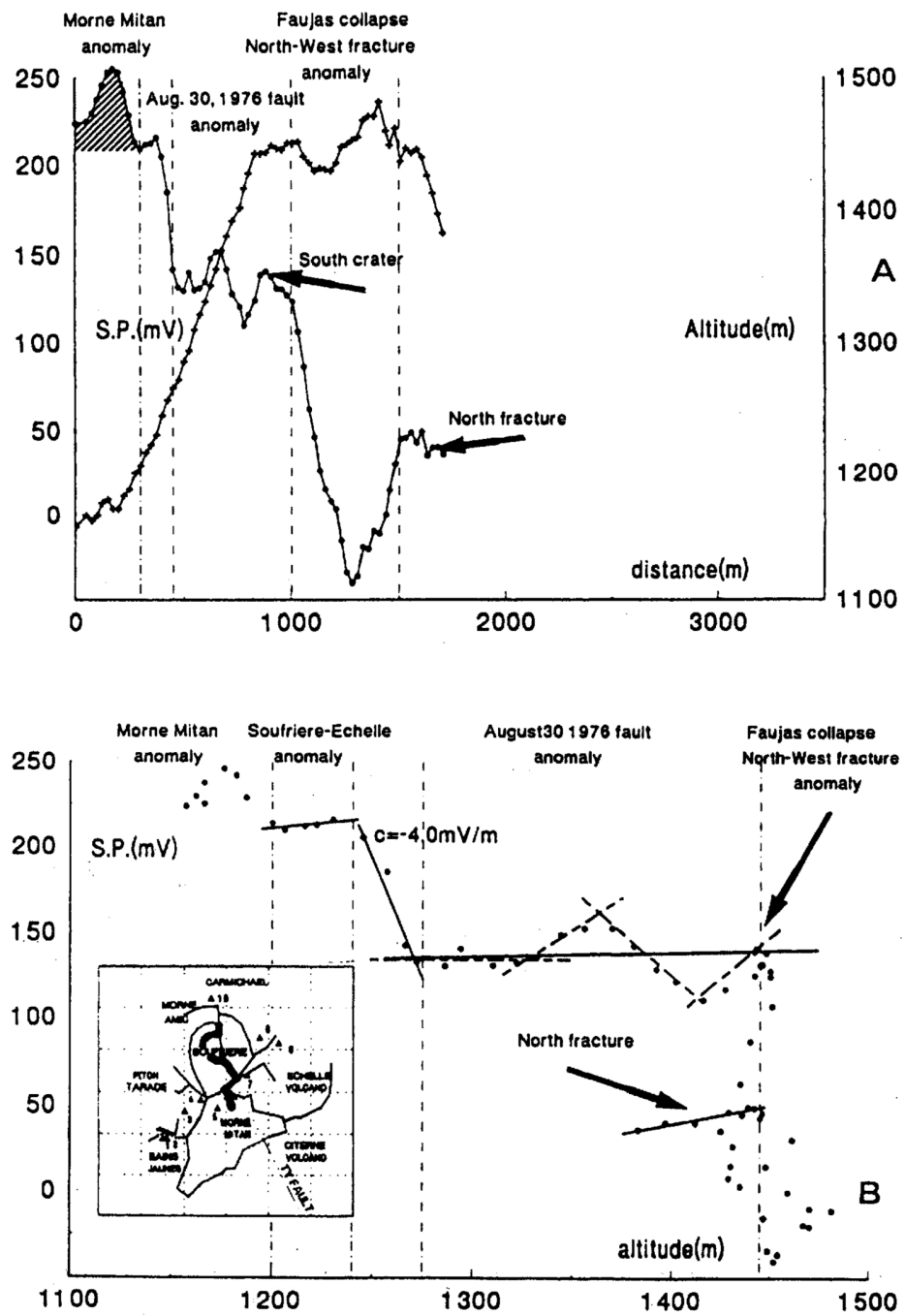

Fig. 6. A: S.P. anomalies and associated topography of Morne Mitan-North fault survey versus distance. See Fig. 1 for the signification of triangles. Dashed areas correspond to positive anomalous zones. B: S.P. values versus altitude. 

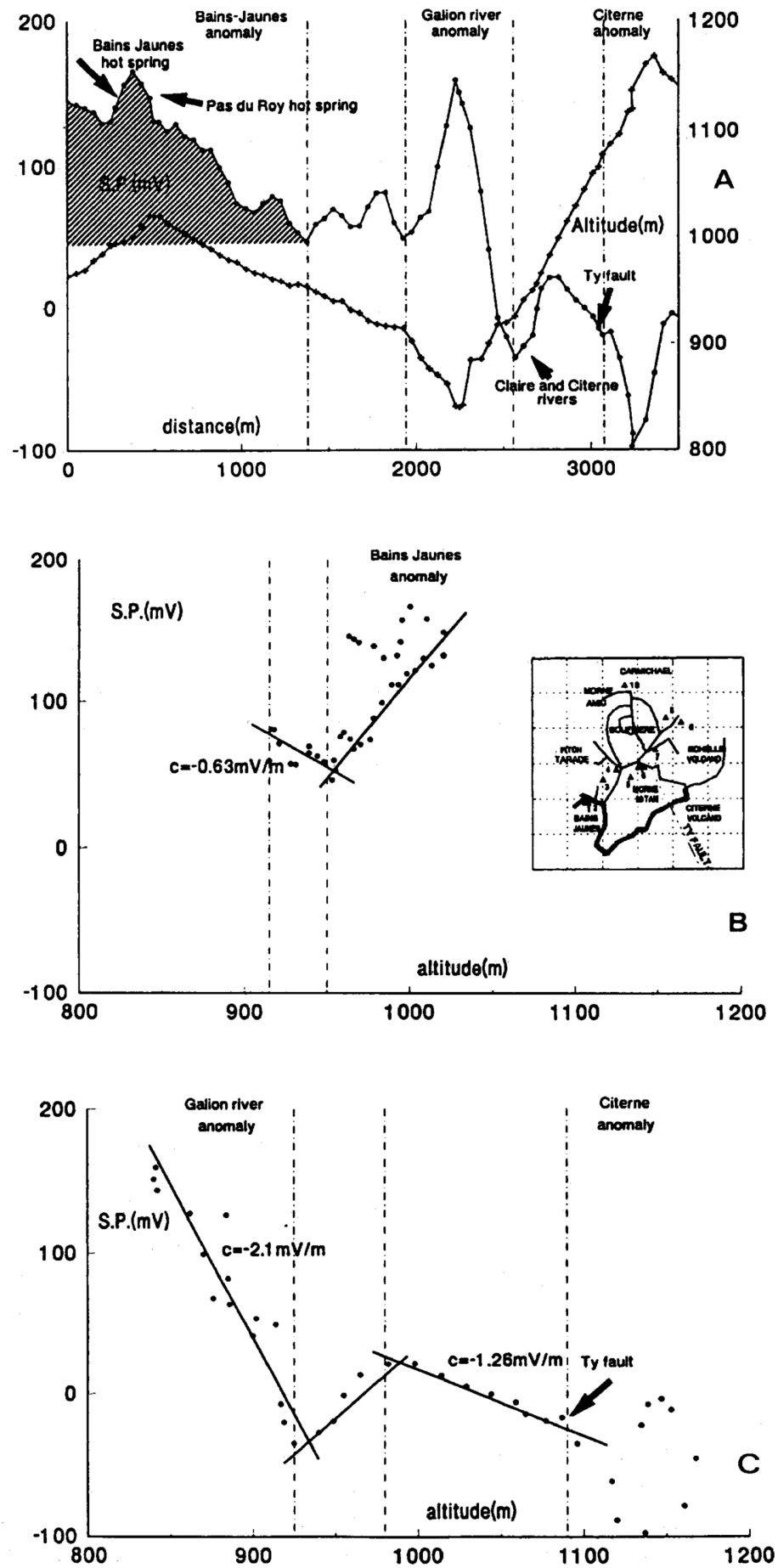

Fig. 7. A: S.P. anomalies and associated topography of Bains Jaunes-Galion river-Citerne volcano survey versus distance. See Fig. 1 for the signification of triangles. Dashed areas correspond to positive anomalous zones. B: S.P. values versus altitude till the beginning of Galion river anomaly. C: S.P. values versus altitude beyond Galion river anomaly. 
and Bonneton, 1984) in which fumarolic activity is confined. On the summit thermal exchanges are spreading from Dolomieu (in the south-west) to July 8, 1976 fault (in the east'south-east sector, Fig. 8).

\subsection{Bains Jaunes hot springs-Galion river-Citerne volcano profile}

This survey starts near Bains Jaunes hot springs, goes through Galion river and ends on Citerne volcano at the reference $R$ (Fig. 1A). One can consider the survey in three main parts (Figs. 7A, 7B, 7C and 8): First from the west to about $950 \mathrm{~m}$ of elevation a relative positive S.P. anomaly (Bains Jaunes anomaly) is associated with warm ground water circulations. The extension is larger than $1200 \mathrm{~m}$. The maximum of amplitude is observed near the new resurgence Pas du Roy (less than $100 \mathrm{mV}$ ). Second, a topographic S.P. effect is due to Galion river (Galion river anomaly on Fig. 7A). It is representative of water circulations driven by rainfalls in Galion river. The variation rate between S.P. values and the elevation is $-2.1 \mathrm{mV} / \mathrm{m}$. The behaviour of the S.P. anomalies changes after the junction of Claire and Citerne rivers where the survey is nearer to the fumarolic zones. Third the regional Ty fault sharply modifies the general feature of the profile giving rise to the sharp negative Citerne anomaly the amplitude of which is less than $-100 \mathrm{mV}$ (Fig. 7C).

Bains Jaunes hot springs-Galion river-Citerne volcano, and Pas du Roy-Morne Mitan-Citerne volcano profiles suggest that large thermal exchanges due to warm ground water flows are present at the south-west of Soufrière dome. Other smaller surveys strengthen this assumption (Fig. 1A). Water flows, issued from Soufrière dome, are limited on the west hand side by Dolomieu fracture (Figs. 1B, 4A and 8). Water flows downwards Savane à Mûlets and are channelled in a south-west direction towards Bains Jaunes hot springs. No high S.P. gradients are evidenced along this water channelling and this result is in well accordance with the moderate temperatures measured at Savane à Mûlets borehole $\left(29^{\circ} \mathrm{C}\right)$ and at outcrops: Tarade hot spring: $26.5^{\circ} \mathrm{C}$, Bains Jaunes hot spring: $26.5^{\circ} \mathrm{C}$, Pas du Roy hot spring: $30^{\circ} \mathrm{C}$.

\section{S.P. Cartography and Fluids Flows}

The general features of the S.P. anomalies on Soufrière of Guadeloupe is presented in Fig. 8. There is no enough data available to compute the right interpolated S.P. values at the north-east of Echelle cone and at the south-east of Citerne volcano. In spite of these uncertainties, one can underline several main results.

\subsection{On Soufrière dome}

Soufrière summit is the seat of high negative and of diffuse positive S.P. anomalies. The sharp negative anomaly is centered on the north-west part of the dome enclosing Faujas collapse and North-West fracture. In this area and till Soufrière center S.P. anomalies evidences no driven fluids upflow. The present south active zone is spreading between Dolomieu fracture and 1956 fault with a peak of anomaly straight above South crater $(140 \mathrm{mV})$. These distinct negative and positive S.P. anomalies suppose that convective thermal exchanges are strongly channelled along pits, fractures and faults. Between them hydrothermal alteration has clogged up interstitial pore networks, and argillization precludes any convective subhorizontal fluids circulations near the ground surface.

\subsection{At Soufrière dome basis}

Figure 8 shows an outstanding feature of the S.P. anomalies at the dome basis.

A ring of smooth positive anomaly $(>140 \mathrm{mV})$ encloses the dome except on the north $\cdot$ west sector. This ring is clearly correlated with crater Amic wall in which Soufrière dome has taken place. It is also correlated with the location of ancient and/or recent fumarolic areas: Colardeau fumaroles, Carbet-Echelle hot spring, Chaudières-Souffleur fumaroles, Echelle col borehole, Morne Mitan fumarolic area, Galion outcrop, Savane à Mûlets borehole. This contact zone between Soufrière and Amic crater favours thermal exchanges between meteoric waters percolating through the massif, and upward reheated fluids. S.P. anomalies are larger where Amic dome parts still subsist (Echelle col, Fig. 1B). The convective system 


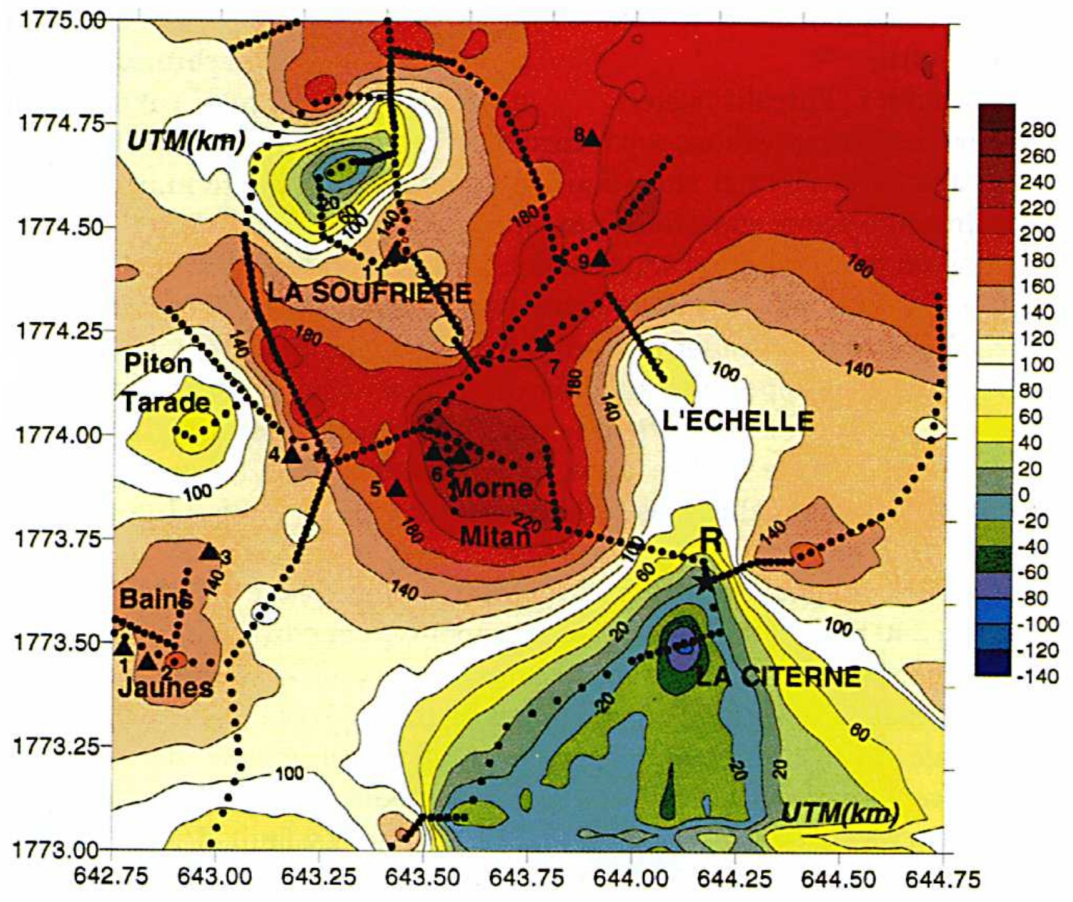

Fig. 8. S.P. cartography of Soufrière (July 1992). R is the reference station.

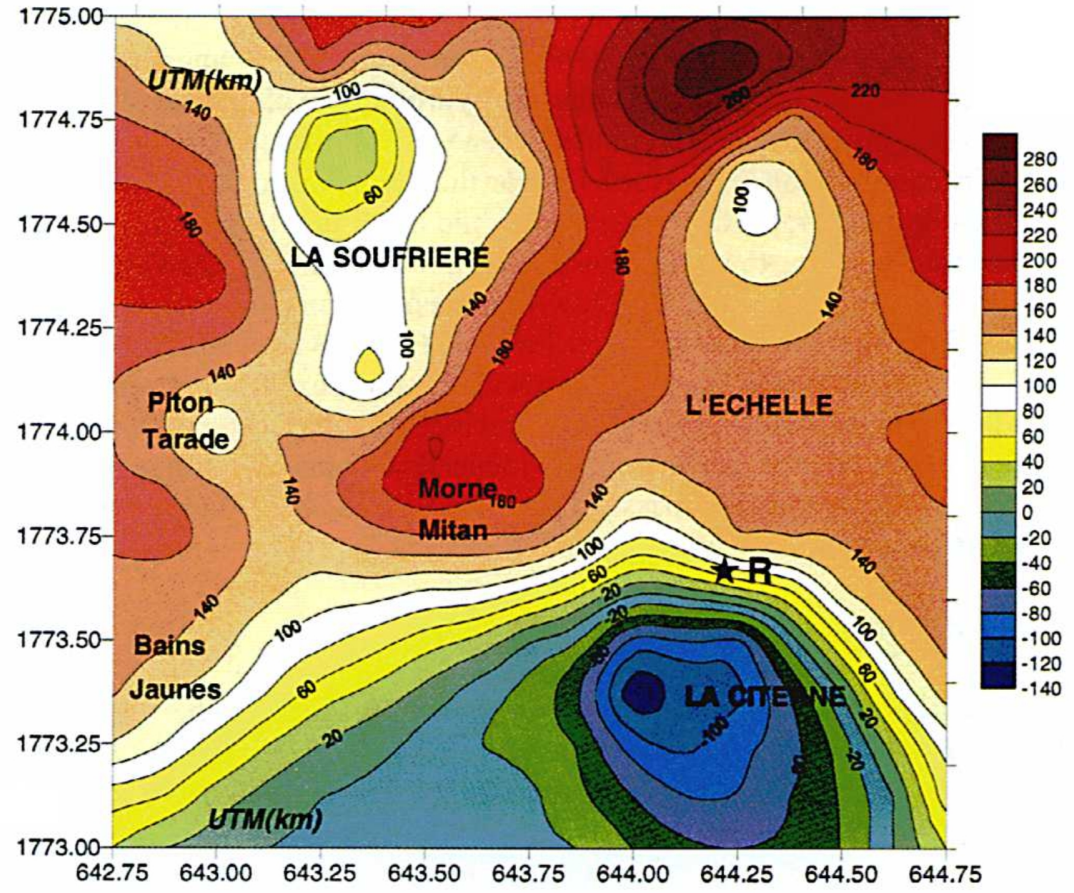

Fig. 9. S.P. cartography of Soufrière (July 1987) (after Pham et al., 1990). R is the reference station. 
between Soufrière dome and Echelle cone takes its source in the existing contact zone between the inner Amic crater wall and Soufrière dome. Meteoric water flows downward till impermeable beds, accumulates, and constitutes water tables. Phreatic waters are superficial and of weak volume; their temperature variations and geochemical compositions are affected by seasonal changes. During volcanic quietness periods argillization and hydrothermal alteration are going on to generate impermeable levels, and to isolate water tables. In some years, superficial phreatic tables are drained off and their temperatures are decreasing. Depending on the location of water tables along the crater walls, fluids are flowing towards the north or the south. For example, it is noteworthy that during the last 15 years the temperature decay at Echelle col borehole bottom is similar to Carbet-Echelle outcrop one (Zlotnicki et al., 1992). This temperature decrease and the disappearance of fumarolic activity should not be considered as a vanishing volcanic activity but rather as more difficult thermal convective exchanges issued from the magma supply. This hypothesis is supported by the smooth, slow, extension of the S.P. anomalies which are beginning to obliterate individual S.P. anomalies observed along superficial faults (1956, Breislach, July and August, 1976, faults).

The largest positive S.P. anomaly is centered on Morne Mitan where the width and the amplitude are respectively $700 \mathrm{~m}$ and $240 \mathrm{mV}$. In this area, water channellings are difficult to appraise. The horseshoe trace of Amic crater disappears, the caldera wall is no more observed. The regional Ty fault seems to strike against Echelle cone without any straight connection with the superficial August 30, 1976 fault. Morne Mitan could be the node of several tectonic accidents, and the receptacle of high thermal convective systems and down flow phreatic waters. This hypothesis could explain the large, high, steady state, thermal area observed on Morne Mitan, and here and there along Ty fault. The sharp steep S.P., $60 \mathrm{mV}$, anomaly evidenced on Pas du Roy-Morne Mitan-Citerne volcano survey could be the electric signature of the buried south extension of the North fault. Therefore, this accident could partially separate two kinds of phreatic waters, one peripheric due to Amic crater wall and Ty fault, and the second from Soufrière dome itself.

A localized-200 m wide, $200 \mathrm{mV}$ in amplitude - positive S.P. anomaly is spreading on the southwest flank of Soufrière dome. This anomaly, maximum along Dolomieu fracture is blocked by Tarade negative anomaly (Figs. 4A and 8). On Soufrière summit positive S.P. anomalies concern the southwest-south-east sector. Thermal exchanges emphasize hydrothermal alteration of superficial geological beds. Ground water is flowing to the contact zone between Soufrière dome and Echelle cone, and is locked, on the west side, by the continuation of the North fault on the south flank of the volcano. In the south southwest part of the dome ground water cannot extend to the north due to Dolomieu fracture. This water channelling escapes from the dome towards Bains Jaunes hot springs. It is noteworthy that the smooth and large S.P. anomalies are well correlated with low homogenous temperatures measured at outcrops or boreholes: Savane à Mûlets borehole: $29^{\circ} \mathrm{C}$, Piton Tarade: $26.5^{\circ} \mathrm{C}$, Bains Jaunes: $26^{\circ} \mathrm{C}$, Pas du Roy: $30^{\circ} \mathrm{C}$ (Figs. 1A and 1B). This result is also in accordance with the trace experiment performed by Bigot et al. (1994). They have have poured iodide inside Tarissan pit located at the center of Soufrière dome (Fig. 1B). About three months later iodide traces were only evidenced at Bains Jaunes hot springs showing a very particular underground waters canalization issued from Soufrière dome. (At that time neither Piton Tarade nor Pas du Roy hot springs were flowing.)

\section{Evolution of S.P. Anomalies between 1987 and 1992}

An S.P. survey has been conducted in July 1987 on Soufrière volcano when the volcano did not show any activity (Pham et al., 1990). The sampling rate was about $50 \mathrm{~m}$. Original data are not available. For our purpose the relative, 1987, reference $\mathrm{R}$ has been reported to the same, 1992, reference point R (Fig. 9). Only general trends of interpolated curves can be discussed.

In 1987 the entire dome of Soufrière was the seat of negative S.P. anomalies. The sharp negative anomaly associated with Faujas collapse and North-West fracture was already observed with similar amplitude and pattern. The negative anomaly extended to the south part of the dome. No anomaly was 
evidenced along August 30, 1976 fault. The only positive S.P. anomalies area was the contact zone between Soufrière dome and Echelle cone. Morne Mitan fumarolic area presented a small- $100 \mathrm{~m}$ wideanomaly, the amplitude of which was $200 \mathrm{mV}$.

In regard with the 1992 survey Soufrière has developed, in five years, large positive S.P. anomalies.

- Positive S.P. anomaly, along the contact zone between Soufrière dome and Echelle cone, has extended around Soufrière dome. The main part of the contact zone between Morne Amic crater and Soufrière is now submitted to thermal exchanges between meteoric waters and reheated upward fluids. The smooth and large extension of the S.P. anomalies leads to suppose that thermal exchanges are essentially made by convective exchanges without reopening of water channellings by fracturation.

- Positive Morne Mitan anomaly now covers a larger zone, but the amplitude is still on the same order of magnitude: $220 \mathrm{mV}$. The main evolution of the S.P. maps concerns the south-west flank of Soufrière dome. The negative 1987 anomaly $(80 \mathrm{mV})$ has disappeared and has given place to a $180 \mathrm{mV}$ anomaly. The north border of this new anomalous zone is to associate with Dolomieu fracture. Till now this fracture seems to prevent the extension of the S.P. anomalies to the north.

In comparison with 1987 survey, the south Soufrière flank is now submitted to a smooth and relatively large positive anomaly which is developing till Bains Jaunes and Pas du Roy outcrops. The main ground water, issued from the dome, escapes from it in the south-west direction and essentially re-appears at Bains Jaunes hot springs.

At the present time S.P. anomalies are only surrounded to Echelle col and Soufrière south flank. It is important to underline that warm water channelling, from the dome towards the south, emphasizes hydrothermal alteration of a large part of the dome: the south-west-south-east sector. The corresponding dome volume which is not held by any crater wall (as it is on the east flank with Echelle cone) could directly collapse in Galion river giving rise to a huge lahar (estimated volume: $15 \times 10^{6} \mathrm{~m}^{3}$, Figs. $1 \mathrm{~A}$ and $1 \mathrm{~B}$ ).

\section{Conclusion}

The method of Self Potential catography is easy to use on volcanoes. The S.P. map provides information on superficial structural accidents and on hydrogeological systems when anomalous thermal zones and/or groundwaters exist. On Soufrière of Guadeloupe, the S.P. map clearly evidences the faults which cut the dome. Some of them have no trace at the ground surface although they are of prime importance in ground waters channellings: Dolomieu fracture and the south extension of the North fault. On Soufrière volcano S.P. values are weak, they do not reach $250 \mathrm{mV}$ compared with $1.9 \mathrm{~V}$ on the basaltic Fournaise volcano (Zlotnicki et al., 1994). The smooth and weak anomalies are probably due to the global argillization of the massif which homogenize the physical parameters generating the Self Potential: conductivity, porosity, permeability. In 1992 the S.P. map points out that a ring of positive anomaly associatecd with the inner Amic crater wall. This anomalous zone has largely developed in the last 5 years. Ground waters channellings have been identified. First, the contact zone between Soufrière dome and Echelle cone is the focusing point of small watersheds. Water table is superficial and pours out to the north (Echelle-Carbet hot spring) and the south (Matylis river and Morne Mitan). Second, the main part of ground water issued from the dome escapes from it in the south-west direction, blocked to the north by Dolomieu fracture and Piton Tarade. The largest outcrops are observed a few kilometers away at Bains Jaunes hot springs.

The S.P. map shows that the south-west-south-east sector of the dome is submitted to a strong hydrothermal alteration by ground water. At the opposite of the other parts of Soufrière dome this sector is opened towards the south. No cone or crater wall is there to stop a landslide to discharge in Galion river.

What happened and what could occurred on Soufrière volcano? Due to high rainfalls in a tropical climate clogging up, argillization and hydrothermal alteration has pursued on Soufrière massif since the last 1976-1977 seismovolcanic crisis. Fumarolic activity has slowly migrated from the dome to the periphery except in the upper part of August 30, 1976 fault and in South crater. Along the east inner Amic crater wall temperatures in borehole and at outcrops have decreased. Convective thermal exchanges 
between heat supplied by the magma reservoir and meteoric waters have become more and more difficult. Phreatic waters were progressively isolated in watertight beds. Superficial water tables were drained off while deeper water tables were slowly reheated, without large thermal transfers till the ground surface. No new magma batch coming from a deep source into the superficial magma reservoir, located at about $6 \mathrm{~km}$ depth, was necessary to generate the observed 1992 seismovolcanic crisis. The magma body continuously supplies thermal energy within the massif. Pressure has increased till a threshold beyond which reopening of cracks has occurred and has released a slight part of thermal stresses. Argillization and hydrothermal alteration is going on to generate a closing system and can conceal any deep activity since watertight beds are isolating water tables. It is difficult to assume that thermal energy released during May-December 1992 was enough to recover a very long quiet period according to the small released total seismic energy (less than $4 \times 10^{7}$ Joules).

We greatly thank A. Milles for his important contribution to the field experiment.

\section{REFERENCES}

Aubert, M. and G. Kieffer, Evolution d'une intrusion magmatique dans le flanc sud de l'Etna. Résultats des mesures de potentiel spontané (P.S.) et essai d'interprétation de l'éruption de 1983, C.R. Acad. Sci. Paris, 298, 2, 379-382, 1984.

Ballestracci, R. and Y. Nishida, Fracturing associated with the 1977-1978 eruption of Usu volcano, north Japan, as revealed by geophysical measurements, J. Volcanol. Geotherm. Res., 34, 107-121, 1987.

Bigot, S. and G. Hammouya, Surveillance hydrogéochimique de la Soufrière de Guadeloupe, 1979-1985: diminution de l'activité ou confinement?, C.R. Acad. Sci. Paris, 304, 2, 757-760, 1987.

Bigot, S., G. Boudon, M. Semet, and G. Hammouya, Traçage chimique de la circulation des eause souterraines sur le volcan de la Grande Découverte (la Soufrière), Guadeloupe, submitted to C. R. Acad. Sci. Paris.

Boudon, G., M. Semet, and P. M. Vincent, Magma and hydrothermally driven sector collapses: The 3100 and 11500 y. B.P. eruptions of La Grande Découverte (La Soufrière) volcano, Guadeloupe, French west Indies, J. Volcanol. Geotherm. Res., 33, 317-323, 1987.

Corwin, R. F. and D. B. Hoover, The self-potential method in geothermal exploration, Geophysics, 44, 226-245, 1979.

Dorel, J. and M. Feuillard, Note sur la crise sismo-volcanique à la Soufrière de Guadeloupe 1975-1977, Bull. Volcanol., 43, 295302, 1980.

Dorel, J., S. Echenbrenner, and M. Feuillard, Les volcans actifs de la Guadeloupe et de la Martinique-Petites Antilles, Bull. Volcanol., 26, 359-381, 1972.

Feuillard, M., Etudes thermiques à la Soufrière de la Guadeloupe, Bull. B.R.G.M., 2, 375-388, 1976.

Feuillard, M., C. J. Allègre, G. Brandeis, R. Gaulon, J. L. Le Mouël, J. C. Mercier, J. P. Pozzi, and M. Semet, The 1975-1977 crisis of La Soufrière de Guadeloupe (F. W. I.): a still-born magmatic eruption, J. Volcanol. Geotherm. Res., 16, 317-334, 1983.

Fitterman, D. V., Electrokinetic and magnetic anomalies associated with dilatant regions in a layered Earth, J. Geophys. Res., 83, 5923-5928, 1978.

Goguel, J., Le mécanisme des éruptions phréatiques dans l'activité volclanique, C.R. Somm. Soc. Géol. Fr., 5, $277-279,1977$.

I.P.G. report, Crise sismo-éruptive de la Soufrière de Guadeloupe (Novembre 1976-Avril 1977). Institut de Physique du Globe de Paris, Rapport Paris, France, 161 pp., 1976.

Ishido, T., T. Kikuchi, and M. Sugihara, Mapping thermally driven upflows by the self-potential method, Geophys. Monograph., 47, IUGG Vol. 2, pp. 151-158, AGU, 1989.

Jackson, D. B. and J. Kauahikaua, Regional self-potential anomalies at Kilauea volcano, U.S. Geol. Survey Prof. Paper 1350, 40, pp. 947-959, 1987.

Jolivet, J., La crise volcanique de 1956 à La Soufrière de la Guadeloupe, Ann. Geophys., 11, 305-322, 1958.

Julien, P. and J. R. Bonneton, Etude néotectonique de la Soufrière de Guadeloupe, C.R. Acad. Sci. Paris, 2, 298, 907-909, 1984.

Lénat, J. F., Structure et dynamique interne d'un volcan basaltique intraplaque océanique: Le Piton de la Fournaise (lle de la Réunion), Thèse, 380 pp., Univ. Bl. Pascal, Clermont-Ferrand (France), 1987.

Massenet, F. and V. N. Pham, Mapping and surveillance of active fissure zones on a volcano by the self potential method, Etna, Sicily, J. Volcanol. Geotherm. Res., 24, 315-338, 1985.

Mitzutani, H., T. Ishido, T. Yokokura, and S. Ohnishi, Electrokinetic phenomena associated with earthquakes, Geophys. Res. Lett., 3, 365-368, 1976.

Nishida, Y. and H. Tomiya, Self Potential studies in volcanic areas, Usu volcano, J. Fac. Sci. Hokkaido Univ., 7, 8, 2, 173-180, 1987.

Pascaline, H., S. Benaugis, J. J. Jérémie, and B. Blavoux, Hydrochimie et circulation des eaux de sources chaudes du massif de 
la Soufrière, Guadeloupe, Bull. Mus. natn. Hist. nat., Paris, 4, 3-4, 137-155, 1982.

Pham, V. N., D. Boyer, G. Boudon, S. Gruszow, and J. Zlotnicki, Anomalies de polarisation spontanée sur la Soufrière de Guadeloupe. Relations avec la structure interne du volcan, C.R. Acad. Sci. Paris, 2, 310, 815-821, 1990.

Robson, J. R. and J. F. Tomblin, Catalogue of the active volcanoes and solfatara fields of the west Indies, in Catalogue of the Actives Volcanoes of the World, part XX, Int. Assoc. Volcanol., Napoli, Italy, 1966.

Sato, M. and H. M. Mooney, The electrochemical mechanism of sulfide Self Potentials, Geophysics, 35, 226-249, 1960.

Vincent, P. M., N. Vatin-Pérignon, M. Semet, and J. L. Cheminée, Le dôme de La Soufrière (Guadeloupe): Son âge et son mode de mise en place, C.R. Acad. Sci., D, 288, 51-54, 1979.

Zablocki, C. J., Mapping thermal anomalies on an active volcano by the self-potential method, Kilauea, Hawaii, Proc. 2 nd U.N. Symposium on the Development and Use of Geothermal Resources, San Francisco, 1975, 2, 1299-1309, 1976.

Zlotnicki, J., Magnetic measurements on La Soufrière volcano, Guadeloupe (Lesser Antilles) 1976-1977: a re-examination of the volcanomagnetic effects observed during the volcanic crisis of 1976-1977, J. Volcanol. Geotherm. Res., 30, 83-116, 1986.

Zlotnicki, J., G. boudon, and J. L. Le Mouël, The volcanic activity of La Soufrière of Guadeloupe (Lesser Antilles): structural and tectonic implications, J. Volcanol. Geotherm. Res., 49, 91-104, 1992.

Zlotnicki, J., S. Michel, and C. Annen, Anomalies de polarisation spontanée et systèmes convectifs sur le volcan du Piton de la Fournaise (île de la Réunion), C.R. Acad. Sci. Paris, 318, 1325-1331, 1994.

Zodhy, A. A. R., L. A. Anderson, and L. J. P. Muffler, Resistivity, self potential and induced polarization surveys of a vapordominated geothermal system, Geophysics, 38, 1130-1144, 1973. 